\title{
Application of Taguchi method to investigate the effect of temperature, heating time, concentration and particle size on improved gel spinning process of UHMWPE
}

\section{REZUMAT - ABSTRACT}

Aplicarea metodei Taguchi pentru a investiga efectul temperaturii, al timpului de încălzire, concentrației și dimensiunii particulelor asupra procesului de filare îmbunătățită cu gel a UHMWPE

În cadrul acestui studiu, filamentele UHMWPE au fost extrudate utilizând procedeul de filare cu gel pe bază de terpen nou dezvoltat. Modelul experimental factorial fracțional Taguchi a fost conceput pentru a studia impactul diferiților factori asupra tenacității fibrelor. Filamentele extrudate au fost caracterizate prin luarea în considerare a tenacității filamentelor ca răspuns. Extrudarea a fost efectuată folosind un procedeu de filare cu gel pe bază de terpen dezvoltat de autor, care utilizează terpen ecologic (ulei de portocală) în locul substanțelor petrochimice utilizate în extrudarea convențională a UHMWPE. Au fost utilizați patru parametri de procesare selectați, iar efectul lor asupra tenacității filamentelor rezultate a fost evaluat utilizând metode statistice standard. S-a constatat că timpul de încălzire și concentrația exercită un effect semnificativ asupra tenacității filamentelor. În plus, interacțiunea dintre concentrație și dimensiunea particulelor, temperatură și concentrație, timpul de încălzire și concentrație au indicat un efect major asupra răspunsului.

Cuvinte-cheie: UHMWPE, terpen, ecologic, tenacitate, filare cu gel

Application of Taguchi method to investigate the effect of temperature, heating time, concentration and particle size on improved gel spinning process of UHMWPE

In this research UHMWPE filaments were extruded utilising newly developed terpene based gel spinning process. Taguchi's fractional factorial experimental design was implemented to study the impact of different factors on the tenacity of the fibres. Extruded filaments were characterized by taking filament tenacity as response. The extrusion was carried out utilising terpene base gel spinning process developed by the author reported previously, which uses environmentally friendly terpene (orange oil) instead of petrochemicals used in the conventional extrusion of UHMWPE. Four selected processing parameters were used and their effect on the tenacity of resultant filaments was assessed using standard statistical methods. It was found that the concentration and heating time exerts significant effect on the tenacity of filaments. In addition, interaction between concentration and particle size, temperature and concentration, heating time and concentration indicated major effect on the response.

Keywords: UHMWPE, terpene, environmentally friendly, tenacity, gel spinning

\section{INTRODUCTION}

Ultra high molecular weight polyethylene (UHMWPE) has very high melt viscosity; conventional methods of extrusion cannot be applied for the production of fibres. One of the earliest methods used to produce the UHMWPE fibres was surface growth method. Contrary to other manufacturing methods of UHMWPE which consists of at least two or more stages [1]. In surface growth method fibres are produced through couette flow of a dilute solution. Fibrous crystals grow on the surface of the rotating internal cylinder. Fibres are produced by pulling out the growing fibrous crystal [2-6]. There are number of techniques to achieve the surface growth; Zwijnenburg developed one of the simplest method [3]. The technique proposed by Zwijnenburg composed of Teflon rotor and beaker. The Teflon rotor is placed in the middle of the beaker. A tube is connected to the beaker through which seed yarn is passed on to the cylinder. The seed yarn is pulled by the take up roller. Tension measuring device is installed to measure the tension of the yarn between tube and take up roller. UHMWPE is dissolved in the p-xylene solution at $130^{\circ} \mathrm{C}$. The rotor is set in motion. The seed yarn is introduced into the system through the tube. The rotation of the rotor catches the seed yarn. The rotation brings the yarn in contact with the rotor which initiates the surface growth. The seed yarn is pulled out and wound on the take up roller. Winding speed of take up roller is adjusted according the rate of fibrous crystal growth. The process continues for days [1]. The same design was used by Braham and Keller they manged to achieve high modulus [2]. Kavesh and his co-workers developed a slightly different surface growth method [4]. Prevorsek made comparison between surface growth and other methods [7]. He argued that the fibres produced by the surface growth apparatus have exceptionally high strength and modulus [8], which is due to the reduced number of chain folding during this process compared to melt spinning process. 
However this process is only suitable for producing monofilament for fishing lines, dental floss and surgical sutures. The process is not capable of producing fine cross section multifilament [7]. Additionally the control of fibre diameter is also a challenge in surface growth method.

An alternate to the surface growth is gel spinning process. Multifilament with predetermined thickness can be produced by gel spinning in contrast to surface growth. The control of fibre thickness is easier to control in gel spinning. Compared to UHMWPE normal polyethylene contains less oriented molecules which results in weaker fibres. To impart strength in fibre the molecule chains are stretched to orientate and crystallise the chain along the axis of the fibres. Stronger fibres can only be achieved with long enough polymer chains to give rise to chain interactions. Hence to achieve very strong fibres, ultra high molecular weight PE is used as starting material. UHMWPE contains very long polymer chains; however the longer polymer chains give rise to chain entanglements. These chain entanglements affect the melt flow index of the UHMWPE making it impossible to be extruded by conversational extrusion methods. Furthermore, the chain entanglements limit the ability of the fibres to draw. Drawing plays a vital role in achieving the high strength fibres by orientating the polymer chains along the axis of the fibre. Gel spinning process is used to overcome these problems. In the first of step of the gel spinning process polymer is dissolved in a solvent to form slurry. This results in the disentanglement of polymer chains, hence making extrusion possible. In the second step of the process the slurry is extruded through a spinneret to produce gel like monofilament or multifilament depending on the spinneret. The disengagement of chains during the extrusion process enables the extruded filaments to be drawn to very high draw ratios. Higher draw ratio make polymer chains highly oriented which results in the fibre with higher strength and modulus. Gel spun fibres can attain an orientation of more than $95 \%$ and up to $85 \%$ crystallinity which give UHMWPE fibres superior properties [9].

In conventional gel spinning process petrochemicals are used to dissolve polymer followed by extrusion of polymer solution [10]. Extrusion of polymer solution produces gel like fibres which contains both polymer and petrochemical solvent. In the second stage gel like fibres are treated with extraction solvent to remove petrochemical solvent. In present work gel spinning was carried out utilizing terpene based gel spinning process developed by author [11] instead of petrochemicals used in conventional gel spinning of UHMWPE. The schematic diagram of newly developed process is shown in figure 1.

There are many factors that influence the gel spinning process. In this research an experimental design was implemented to find out the effect of the concentration, temperature, heating time, particle size and their interactions. Taguchi's method of statistical experimental design was used to identify the effect of processing factors and interaction between various

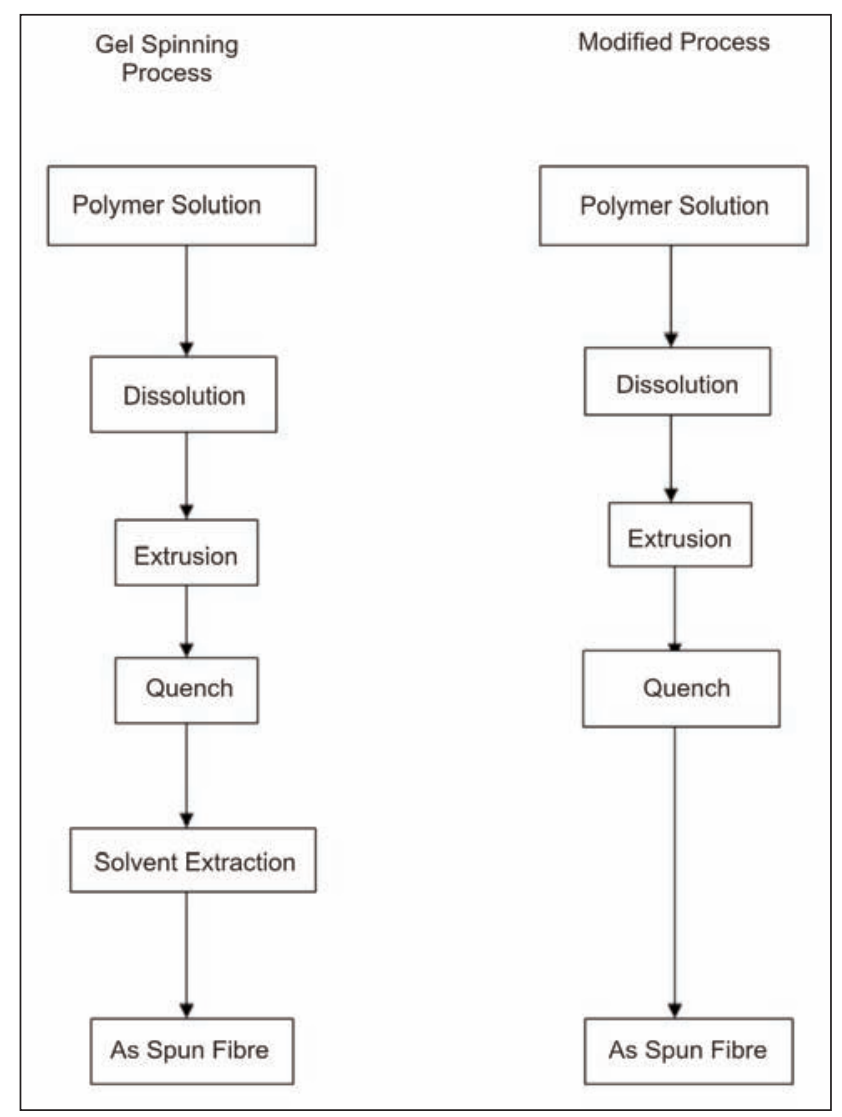

Fig. 1. Comparison between conventional and modified gel spinning process

factors. Taguchi's method of quality control is based on orthogonal array experiments that help in optimizing the process.

\section{EXPERIMENTAL WORK}

\section{Materials and methods}

Ultra high molecular weight polyethylene Gur 4120 with average molecular weight of $5.0 \times 10^{6}$ supplied by the Ticona UK Ltd was used in this work. The polymer density was $0.93 \mathrm{~g} \mathrm{~cm}^{-3}$, with melting point in the range of $130^{\circ} \mathrm{C}-135^{\circ} \mathrm{C}$. Orange oil (terpene) was sourced from Sigma-Aldrich. The boiling point of terpene was $176^{\circ} \mathrm{C}$. 2,6-Di-tetra-butyl-4-methylphenol antioxidant was also supplied by SigmaAldrich.

Samples were prepared as reported previously by the author [11]. Tensile tests were carried out on Instron 3345. Simples were conditioned at $20 \pm 2{ }^{\circ} \mathrm{C}$ and $65 \pm 2 \%$ relative humidity for 24 hours before testing. ASTM standard D 3822 was followed to conduct testing.

\section{Experimental design}

A two level four variables fraction factorial experimental designwas used for the evaluation of variables effect on the as spun fibre strength. Polymer particle size, temperature, heating time and concentration were chosen as variables. Instron tensile tester was used for the testing of as spun fibre strength. The strength of the as spun fibres was used as a response in the experimental design. 
Initial experiments were carried out to set the levels of the experimental design. Due to the novelty of the process no data was available in literature. UHMWPE polymer powder SEM images showed the particle size of the polymer differ greatly. Particles of having size of 150 micron and greater but less than 250 microns were set as level one and particles with greater than 250 microns were set as level two.

Experiments were carried out to find the gelation temperature of polymer in terpene solvent. The gelation starts at $120^{\circ} \mathrm{C}$ therefore level one for temperature was set at $130^{\circ} \mathrm{C}$. Wide range of temperatures had been reported previously for the preparation of solution in different solvents. Since terpene was used in this work it was decided to set the level two at $150^{\circ} \mathrm{C}$ to avoid the excessive evaporation of the terpene during solution preparation process since terpene boils at $176^{\circ} \mathrm{C}$. For setting the heating time there were significant differences in the available literature. Solvent made from decalin were reported to be heated for 40 min while solvent made from paraffin solvent had been reported to be heated for 48 hours. The level one for heating time was set at $1 \mathrm{hr}$ and level two at $3 \mathrm{hr}$. Polymer concentration plays vital role in the final strength of the fibres as reported by several researchers. Experiments conducted by researcher with decalin reported fibre preparation with as low polymer concentration as $0.5 \%$ [12].

However solution made with $0.5 \%$ polymer concentration in paraffin was not extrude able [13]. Experiments were carried out by preparing $0.5 \%, 1 \%$, $2 \%$ and $3 \%$ solution in terpene and extruded on the

Table 1

\begin{tabular}{|l|c|c|}
\hline \multicolumn{1}{|c|}{ Factors } & Low level & High level \\
\hline $\begin{array}{l}\text { Polymer particle } \\
\text { size (A) }\end{array}$ & $150<\mathrm{X}<250$ micron & $\mathrm{Y}<250$ micron \\
\hline Temperature (B) & $130^{\circ} \mathrm{C}$ & $150^{\circ} \mathrm{C}$ \\
\hline Heating time (C) & $1 \mathrm{hr}$ & $3 \mathrm{hr}$ \\
\hline Concentration (D) & $3 \%$ & $5 \%$ \\
\hline
\end{tabular}

$X$ represents the size of the particle which are greater than 150 micron but smaller than 250 microns.

$\mathrm{Y}$ represents the particles size greater than 250 micron. ram extruder to find out the lowest limit of concentration for the preparation of fibre. It was observed the solution having concentration of $0.5 \%$ and $1 \%$ were too thin to be extruded on the ram extruder. Gel fibres were successfully prepared with $2 \%$ concentration and collected on the bobbins but after the removal of the solvent by air drying fibres lost their shape and stuck together. Fibres extruded from 3\% solution kept their fibre form. Hence level for the polymer concentration was set at $3 \%$ and level at $5 \%$. The experimental design and levels are shown in table 1 and table 2 .

\section{RESULTS AND DISCUSSION}

Polymer concentration of the solution affected the strength of the as spun fibres significantly as shown in the pareto chart (figure 2). Combination of polymer concentration and particle size showed inverse relation to fibre strength. Combination of concentration and heating time improves as spun fibre strength considerably followed by heating time and combination of temperature and concentration. Particle size and temperature showed negligible effect.

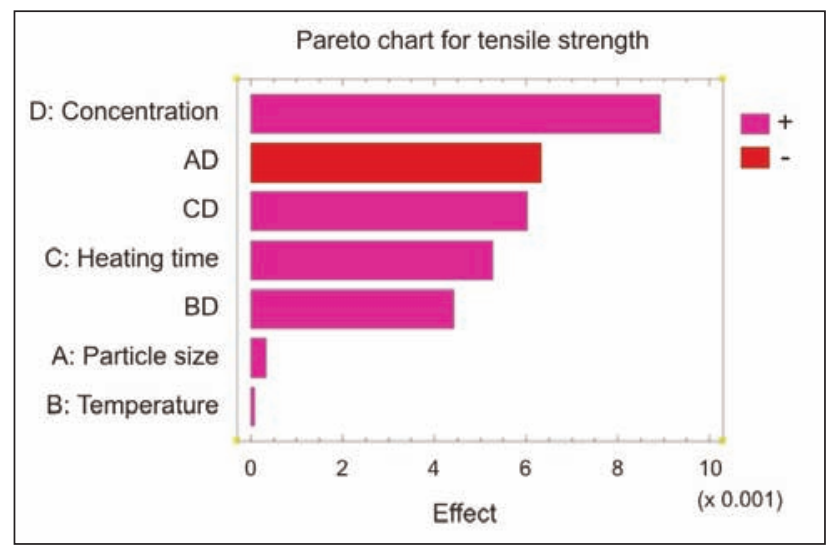

Fig. 2. Effects of different factors on the tensile strength of fibre

Effect of main factors on the response (tensile strength) is shown in figure 3. Particle size showed no significant effect on the strength of the as spun fibres. Changing of particle size levels brought no

Table 2

\begin{tabular}{|c|c|c|c|c|c|}
\hline E.No. & R.O & $\begin{array}{c}\text { Polymer particle size } \\
{[\boldsymbol{\mu \mathrm { m }}]}\end{array}$ & $\begin{array}{c}\text { Temperature } \\
{\left[{ }^{\circ} \mathrm{C}\right]}\end{array}$ & $\begin{array}{c}\text { Heating time } \\
{[\mathrm{hr}]}\end{array}$ & $\begin{array}{c}\text { UHMWPE concentration } \\
{[\%]}\end{array}$ \\
\hline 1 & 3 & $\mathrm{X}$ & 130 & 1 & 3 \\
\hline 2 & 8 & $\mathrm{X}$ & 130 & 3 & 5 \\
\hline 3 & 4 & $\mathrm{X}$ & 150 & 1 & 3 \\
\hline 4 & 7 & $\mathrm{X}$ & 150 & 3 & 5 \\
\hline 5 & 2 & $\mathrm{Y}$ & 130 & 1 & 3 \\
\hline 6 & 5 & $\mathrm{Y}$ & 130 & 3 & 3 \\
\hline 7 & 1 & $\mathrm{Y}$ & 150 & 1 & 5 \\
\hline 8 & 6 & $\mathrm{Y}$ & 150 & 3 & 5 \\
\hline
\end{tabular}

R.O. - Random order in which the experiment was conducted.

E.No. - Experiment number. 


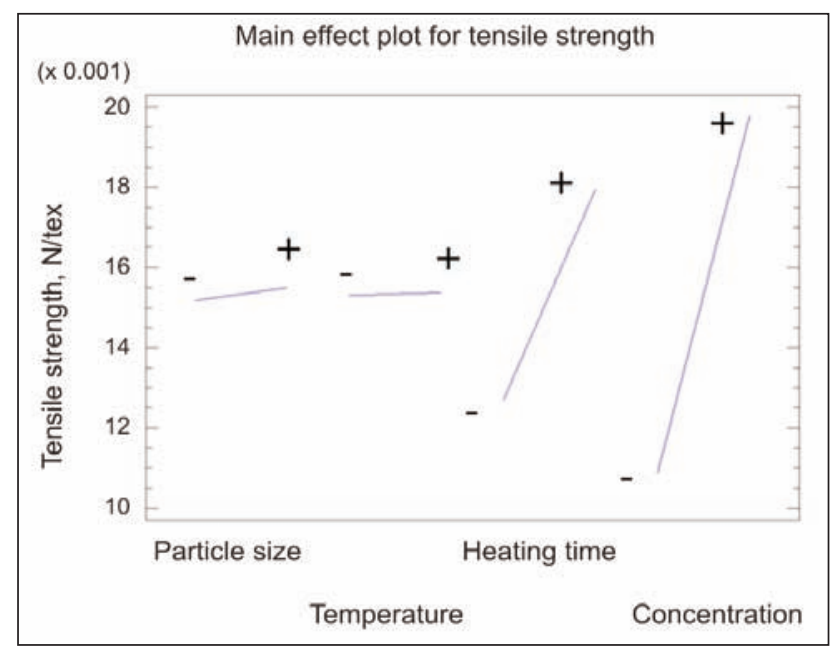

Fig. 3. Effects of main factors level on tensile strength (-ve represents low level, +ve represents high level)

significant change in response. This could be because the irrespective of the size of particle it gets dissolved into the solution and forms homogenous solution. Furthermore the solution was observed to have no undissolved particle indication homogenous mixing of the particles in the solvent. Both level of temperature indicated no change on the response. This could be due to the lower melting of the UHMWPE i.e. $130^{\circ} \mathrm{C}$ to $135^{\circ} \mathrm{Cat}$ both level of temperature UHMWPE got completely dissolved into the solvent. However changes in the level of heating time significantly affects the response. Longer heating time resulted in stronger fibres in contrast to the weaker fibres achieved by reduced heating time.

Concentration of the polymer in the solution significantly affected the strength of the fibre indicated by the vertical line in figure 3 .

The interaction plot is shown infigure 4. It indicates interaction between concentration (D) and Particle size (A). Lower level of $D$ and $A$ results in weaker fibres. High level of $A$ along with lower level of $D$ results in stronger fibres compared to previous combination, however high level of $D$ and low level of $A$

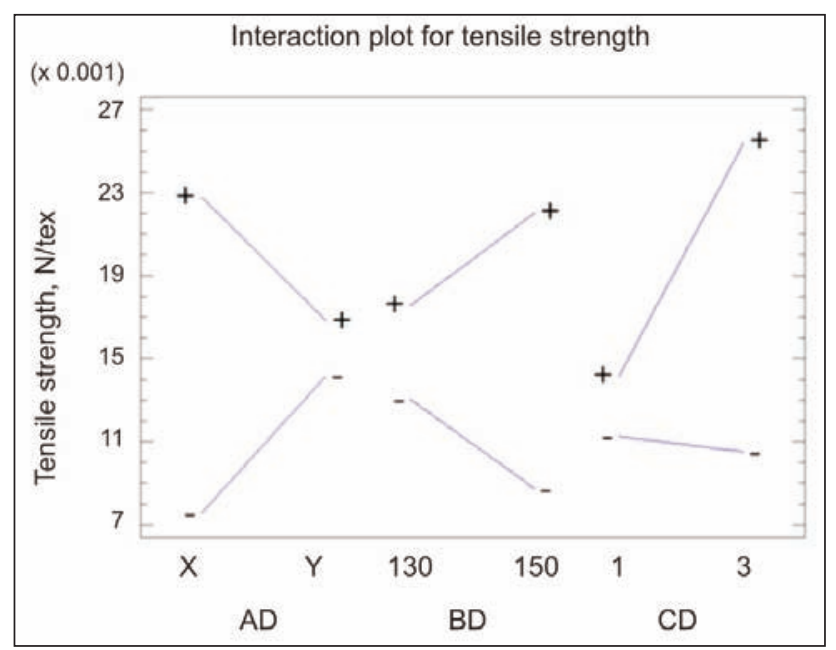

Fig. 4. Interaction Plot for tensile strength (-ve indicates low level of $D$ and +ve indicates high level of $D$ )

results in the maximum response values. Positive interaction was indicated by Temperature $(B)$ and $D$. Lower levels of $D$ and $B$ yield lower response while high levels of both resulted in higher response. Heating time $(C)$ and $D$ showed very high positive interaction Higher values of response were achieved by with higher levels of $C$ and $D$.

\section{CONCLUSION}

The results represented that concentration has significant effect on the strength of the fibres along with combination of heating time and particle size. Results also showed strong interactions between polymer concentration and particle size also between temperature and concentration. Optimal strength can be achieved by keeping concentration and heating time at high levels. However further investigation would be needed to find out the limitation of these factors. Since higher concentration of polymer will result in the polymer chain entanglement hence will result in increased viscosity of the solution. Higher viscosity makes extrusion difficult.

\section{BIBLIOGRAPHY}

[1] Pennings, A.J., et al. Process of preparation and properties of Ulra-High Strength Plyethylene fibers, In: Pure and Applied Chemistry, 1983, 55(5), pp. 777-798.

[2] Barham, P.J. and Keller, A. The achievement of high-modulus polyethylene fibres and the modulus of polyethylene crystals. In: Journal of Polymer Science, 1979. 17(9), p. 3.

[3] Meihuizen, C.E., Pennings, A.J. and Zwijnenburg, A. Process for continuous preparation of fibrous polymer crystals, In: 1979, Stamicarbon, B.V., USA.

[4] Kavesh, S., Prevorsek, D.C. and Wang, D.G. Production of high strength polyethylene filaments, In: 1982, Allied Corporation, USA.

[5] Zwijnenburg, A. and Pennings, A.J. Longitudinal growth of polymer crystals from flowing solutions III. Polyethylene crystals in Couette flow. In: Colloid \& Polymer Science, 1976, 254(10), pp. 868-881.

[6] Torfs, J.C.M. and Pennings, A.J. Longitudinal growth of polymer crystals from flowing solutions. VIII. Mechanism of fiber formation on rotor surface. In: Journal of Applied Polymer science, 1981, 26(1), pp. 303-320. 
[7] Prevorsek, D.C., Spectra: The latest entry in the field if high-performance fibers, in Handbook of fiber science and technology, In: M. lewin, Editor. 1996, Marcel Dekker New York. pp. 25-27.

[8] Pennings, A.J. and Meihuizen, K.E. Polyethylene fibres with ultra-high modulus and strength produced by flow-controlled crystallisation, In: Ultra-High Modulus Polymers, A. Ciferri and I.M. Ward, Editors. 1979, Applied Science Publishers.

[9] Dingene, J.J.V., Gel-Spun high-performance polyethylene fibers, In: High Performance Fibers, J.W.S. Hearle, Editor. 2001, Woodhead. pp. 62-92.

[10] Schaller, R., et al., High-performance polyethylene fibers "Al Dente": improved gel-spinning of ultrahigh molecular weight polyethylene using vegetable oils.In:Macromolecules, 2015. 48(24): pp. 8877-8884.

[11] Rajput, A.W., Aleem, A.U. and Arain, F.A. An Environmentally Friendly Process for the Preparation of UHMWPE As-Spun Fibres.In: International Journal of Polymer Science, 2014. 2014, p. 5.

[12] Matsuo, M. and Manley, R.S.J. Ultradrawing at room temperature of high molecular weight polyethylene. 2. Effect of annealing. In: Macromolecules, 1983. 16(9), pp. 1500-1505.

[13] Smook, J., Flinterman, M. and Pennings, A.J. Influence of spinning/hot drawing conditions on the tensile strength of porous high molecular weight polyethylene. In: Polymer Bulletin, 1980. 2(11), pp. 775-783.

\section{Authors:}

\section{ABDUL WAQAR RAJPUT ${ }^{1}$ \\ BILAL ZAHID ${ }^{2}$ \\ HAFSA JAMSHAID ${ }^{3}$ \\ USMAN ALI ${ }^{1}$ \\ AMIR ABBAS 1 \\ RAJA FAHAD QURESHI ${ }^{4}$}

${ }^{1}$ Technical Textile Research Lab, BZU College of Textile Engineering, Multan, Pakistan

${ }^{2}$ Textile Engineering Department, NED University, Karachi, Pakistan

${ }^{3}$ Department of Knitting, National Textile University, Faisalabad, Pakistan

${ }^{4}$ Department of Textile Engineering, Mehran University of Engineering and Technology, Jamshoro, Pakistan

e-mail: waqar.rajput@bzu.edu.pk; drbilalzahid@neduet.edu.pk; hafsa@ntu.edu.pk; usman.ali@bzu.edu.pk; amir.abbas@bzu.edu.pk; raja.ashraf@faculty.muet.edu.pk

\section{Corresponding author:}

\section{ABDUL WAQAR RAJPUT}

e-mail: waqar.rajput@bzu.edu.pk 